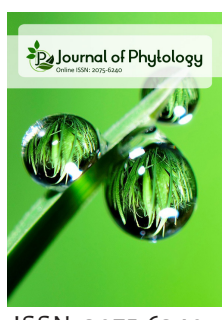

ISSN: $2075-6240$

\title{
Seed quality improvement with fruit extracts in blackgram (Vigna mungo L.)
}

\author{
T. Poovarasan 1*, S. Lakshmi', J. Renugadevi', A. Senthil ${ }^{2}$ \\ 'Department of Seed Science and Technology, Tamil Nadu Agricultural University, Coimbatore - \\ 641003, Tamil Nadu, India, '2Department of Crop Physiology, Tamil Nadu Agricultural University, \\ Coimbatore -641003, Tamil Nadu, India
}

Received: January 19, 2019

Accepted: March 11, 2019

Published: March 18, 2019

*Corresponding Author:

T. Poovarasan

Email: poovarasanvel1996@

gmail.com

\begin{abstract}
The present study was conducted to know the effect of extracts from parts of papaya and pomegranate fruits containing enormous amount of antioxidants on the seed quality parameters of blackgram (Vigna mungo L.). Blackgram seeds were soaked in papaya peel, pulp, seeds and pomegranate peel, seeds extracts viz., 2.5\%,5\%,7.5\% and $10 \%$ concentration for 1 hour. The physiological parameters of soaked seeds were evaluated under laboratory conditions. The results revealed that seeds treated with $2.5 \%$ papaya seed extract recorded high physiological and biochemical changes in terms of field emergence, germination percentage, seedling length, dry matter production, vigour index and $\alpha$ - amylase activity when compared to rest of treatments and control.
\end{abstract}

KEYWORDS: Seed quality, blackgram, papaya, pomegranate fruit part extracts

\section{INTRODUCTION}

Blackgram (Vigna mungo L.), the third most important pulse in India, also called urdbean is having a rich source of protein about $26 \%$. It contributes a major share of protein requirements to the population in India. It is taken as split and also the whole grain and it is crucial for supplement of cereal based diet. It contains approximately $1-1.5 \%$ oil, $3.5-4.5 \%$ fibre, $4.5-5.5 \%$ ash and $62-65 \%$ carbohydrates on dry weight basis and also contains folic acid, vitamin $B$, minerals like iron, calcium, magnesium and potassium.

Seed is an important input in agriculture (quality seed). At harvest, the seeds are of good quality but by the time it reaches the farmers hands, would have deteriorated in quality. Presowing treatment which help in enhancing seed quality like uniform germination, vigour, viability and optimum plant stand in the field. Priming means seeds were partially hydrated so that pre - germinative metabolic mechanisms will be started, then the radicle protrusion will be prevented; at the point seed were dried at original moisture content [1].

Natural antioxidants are rich in fruits and vegetables [2] and the wastes or byproducts are source of potential antioxidants [3]. Papaya (Carica papaya L.) belongs to Caricaceae family, and is being considered as a medicinal plant. Papaya contains flavonoids, vitamins, protease inhibitors, alkaloids, saponins, tannins, minerals and carotenoids. Papaya peel contains a high level of proteins, crude fibre, carbohydrate, ash, fat, and rich in potassium, phosphorus and phytochemical composition like total phenols, flavonoids and tannins [4]. Both macro and micro nutrients $(\mathrm{Na}, \mathrm{Ca}, \mathrm{Mg}, \mathrm{P}, \mathrm{Fe}, \mathrm{Cu}, \mathrm{Zn}$, and $\mathrm{Mn}$ ) are present in the papaya pulp [5]. Papaya seeds contain many biochemicals, glucotropaeolin, benzyl glucosinolates, benzyl isothiocyanate, benzyl thiourea, hentriacontane, $\beta$-sitostrol. Papaya peel and seed extracts contain the high levels antioxidant activity [6].

Pomegranate (Punica granatum) belongs to Punicaceae family. It is one of the oldest edible fruits and extensively used in folk medicine. Pomegranate peel contains various types of antioxidant components like polyphenolic class which includes ellagitannins, flavonoids, proanthocyanidin compounds and minerals such as calcium, magnesium, phosphorus, potassium and sodium [7]. Aril contain high amount of polyphenol, organic acids, minerals, vitamins, and sugars [8]. The antioxidant like polyphenols, crude fibres, vitamins, minerals, sugars, the phytoestrogen coumestrol estrones are present in the pomegranate seeds [9-12]. Antioxidants protect and prevent oxidative deterioration of lipids and maintain the structural and functional integrity of cells in seeds [13]. In order to gain a better understanding of the effect of fruit based antioxidants of papaya and pomegranate, on seed invigouration of blackgram, the study was conducted. 


\section{MATERIALS AND METHODS}

The experiment was conducted to assess the impact of seed treatment with fruit part extracts on physiological parameters of blackgram variety TNAU blackgram CO 6. Genetically pure blackgram seeds variety of CO 6 was procured from Department of Pulses, Tamil Nadu Agricultural University, Coimbatore, which represent the source material for this study. The fruit part extracts of papaya (peel, pulp, seed) and pomegranate (peel, seed) were used for seed treatment, to standardize the optimum concentration of fruits parts extracts. Fruit parts with various concentrations viz., $2.5,5,7.5$ and $10 \%$ of each extract were prepared and seeds were treated and evaluated along with water soaking and nontreated seeds which served as control. Seeds were soaked in the extracts for lhour in 1:1 ratio of seed to solution (weight: volume). After treatment, the seeds were removed rinsed with water, shade dried at room temperature up to its original moisture content and the following seed quality parameters were assessed.

The germination test was carried out by roll towel method with 8 replications 400 seeds in each treatment [14]. The germination test was conducted in the germination room in which $25 \pm 2^{\circ} \mathrm{C}$ and $95 \pm 2 \%$ of temperature and relative humidity $(\mathrm{RH})$, respectively were maintained. At the time of final count root length and shoot length was measured at randomly selected ten healthy seedlings from all replication of every treatment. The selected seedlings are removed without any damage (entire root and shoot) and mean values are expressed in centimeter $(\mathrm{cm})$. For dry matter production, the seedlings selected for the shoot and root length were placed in a paper cover, shade dried for 24 hours and kept at $80 \pm 2^{\circ} \mathrm{C}$ for 24 hours in hot air oven. After cooling in desiccator, weighed and expressed at milligram per 10 seedlings. Vigour index I [15] and Vigour index II [16] were also calculated.

For field emergence, 100 seeds with four replications were sown at flat beds in open field condition. At seventh day end the number of seedlings emerged were counted and expressed in the percentage. The protein content was analyzed by Ali-Khan and Youngs method [17]. $\alpha$-amylase activity was estimated in the treated seeds and control seeds [18]. The data was analyzed statistically adopting the procedure given by Panse and Sukhatme [19].

\section{Fruit part extraction for seed treatment}

Papaya and pomegranate fruits were procured from the orchard of Tamil Nadu Agricultural University, Coimbatore. The fruits were washed with fresh water and the parts were separated; papaya - peel, pulp and seed and also pomegranate - peel and seed. Papaya pulp was used as such without drying because of its higher moisture content. The separated fruit parts of papaya (peel and seed) and pomegranate (peel and seed) were shade dried for $4-5$ days followed by sun drying for $3-5$ days. Then dried fruit parts were finely ground by mini dall mill in the Department of Food Process Engineering, Tamil Nadu Agricultural University, Coimbatore. Fruit parts of various concentrations viz., 2.5, 5, 7.5 and $10 \%$ were prepared by weight per volume with distilled water. Initially various concentration of peel, pulp and seed of papaya. Peel and seed extracts of pomegranate were evaluated for their performance on improving the seed quality, best treatment were alone where considered for further evaluation.

\section{RESULTS AND DISCUSSION}

Seed treated with papaya peel extract at different concentrations showed significant differences in seed germination, root length, shoot length, dry matter, vigour index I and vigour index II. Seeds treated with papaya peel extract at $5 \%$ showed the highest seed germination (77 per cent) when compared to the control (72 per cent) which had the lowest germination per cent. The papaya peel extract $5 \%$ recorded maximum root length $(15.2 \mathrm{~cm})$. Papaya peel extract at $5 \%$ and papaya peel $2.5 \%$ showed maximum shoot length $(12.6 \mathrm{~cm})$, which was on par with papaya peel $7.5 \%$. Dry matter $\left(258 \mathrm{mg}\right.$ seedlings $\left.\mathrm{s}^{-10}\right)$, vigour index I (2138) and vigour index II (19.87) recorded maximum in papaya peel extract at $5 \%$. The minimum value obtained in control for all the parameters (Table 1). Papaya peel contains the vitamin c (Ascorbic acid) it plays a major role in seed quality improvement has increased the seed germination percentage [20]. So it may be the reason for increase the seed quality. Similar result was obtained due to Ascorbic acid had increase the seed quality in parsley, onion and pepper seeds [21].

Different concentration of papaya pulp extracts showed significant differences in various physiological parameters of blackgram seeds. The lowest seed germination was recorded in the control 72 per cent, when compared with highest seed germination in papaya pulp extract at $5 \%(75 \%)$, which was on par with papaya pulp extract $2.5 \%(75 \%)$. The longest root length $(15.7 \mathrm{~cm})$, shoot length $(12.6 \mathrm{~cm})$ and maximum dry matter $\left(254 \mathrm{mg}\right.$ seedlings $\left.\mathrm{s}^{-10}\right)$, vigour index I - 2126 and vigour index II - 19.05 recorded in papaya pulp extract $5 \%$ followed by

Table 1: Effect of seed treatment with papaya peel extract on physiological traits in blackgram

\begin{tabular}{|c|c|c|c|c|c|c|}
\hline Treatment & Germination \% & 6 Shoot length $(\mathrm{cm})$ & Root length $(\mathrm{cm})$ & Dry matter (mg seedlings ${ }^{-10}$ ) & Vigour index I & Vigour index II \\
\hline$\overline{T_{1}-\text { Control }}$ & $72(58.05)$ & 10.8 & 13.8 & 237 & 1771 & 17.06 \\
\hline $\mathrm{T}_{2}-$ Water soaking & $73(58.70)$ & 11.3 & 14.3 & 236 & 1869 & 17.23 \\
\hline $\mathrm{T}_{3}$ - Papaya peel extract $-2.5 \%$ & $75(60.0)$ & 12.6 & 14.7 & 251 & 2048 & 18.83 \\
\hline $\mathrm{T}_{4}$ - Papaya peel extract - $5 \%$ & $77(61.34)$ & 12.6 & 15.2 & 258 & 2138 & 19.87 \\
\hline $\mathrm{T}_{5}$ - Papaya peel extract $-7.5 \%$ & $74(59.34)$ & 12.3 & 14.5 & 249 & 1985 & 18.43 \\
\hline $\mathrm{T}_{6}-$ Papaya peel extract - $10 \%$ & $74(59.34)$ & 12.0 & 14.7 & 241 & 1978 & 17.83 \\
\hline Mean & 74 & 11.9 & 14.5 & 245 & 1965 & 18.21 \\
\hline SEd & 0.64 & 0.21 & 0.20 & 0.003 & 25.00 & 0.20 \\
\hline$C D(P=0.05)$ & 1.35 & 0.44 & 0.43 & 0.006 & 52.53 & 0.41 \\
\hline
\end{tabular}


Table 2: Effect of seed treatment with papaya pulp extract on physiological traits in blackgram

\begin{tabular}{|c|c|c|c|c|c|c|}
\hline Treatment & Germination \% & Shoot length $(\mathrm{cm})$ & Root length $(\mathrm{cm})$ & Dry matter (mg seedlings ${ }^{-10}$ ) & Vigour index I & Vigour index II \\
\hline $\mathrm{T}_{1}$ - Control & $72(58.05)$ & 10.8 & 13.8 & 237 & 1771 & 17.06 \\
\hline $\mathrm{T}_{2}-$ Water soaking & $73(58.70)$ & 11.3 & 14.3 & 236 & 1869 & 17.23 \\
\hline $\mathrm{T}_{3}$ - Papaya pulp extract $-2.5 \%$ & $75(60.0)$ & 12.2 & 14.8 & 249 & 2027 & 18.68 \\
\hline $\mathrm{T}_{4}$ - Papaya pulp extract - $5 \%$ & $75(60.0)$ & 12.6 & 15.7 & 254 & 2126 & 19.05 \\
\hline $\mathrm{T}_{5}$ - Papaya pulp extract $-7.5 \%$ & $74(59.34)$ & 11.9 & 14.3 & 243 & 1939 & 17.98 \\
\hline $\mathrm{T}_{6}$ - Papaya pulp extract - $10 \%$ & $73(58.70)$ & 11.5 & 14.0 & 231 & 1862 & 16.86 \\
\hline Mean & 74 & 11.7 & 14.5 & 242 & 1932 & 17.81 \\
\hline SEd & 0.62 & 0.12 & 0.20 & 0.003 & 25.26 & 0.21 \\
\hline$C D(P=0.05)$ & 1.30 & 0.25 & 0.42 & 0.006 & 53.06 & 0.43 \\
\hline
\end{tabular}

Table 3: Effect of seed treatment with papaya seed extract on physiological traits in blackgram

\begin{tabular}{lcccccc}
\hline Treatment & Germination \% & Shoot length $(\mathrm{cm})$ & Root length $(\mathrm{cm})$ & Dry matter $\left(\mathrm{mg} \mathrm{seedlings}^{-10}\right)$ & Vigour index I & Vigour index II \\
\hline $\mathrm{T}_{1}$ - Control & $72(58.05)$ & 10.8 & 13.8 & 237 & 1771 & 17.06 \\
\hline $\mathrm{T}_{2}$ - Water soaking & $73(58.70)$ & 11.3 & 14.3 & 236 & 1869 \\
\hline $\mathrm{T}_{3}$ - Papaya seed extract - 2.5\% & $80(63.44)$ & 13.7 & 16.8 & 257 & 24.23 \\
\hline $\mathrm{T}_{4}$ - Papaya seed extract - 5\% & $79(62.73)$ & 12.6 & 15.4 & 240 & 2206 \\
\hline $\mathrm{T}_{5}$ - Papaya seed extract - 7.5\% & $75(60.0)$ & 13.3 & 15.4 & 245 & 218.96 \\
\hline $\mathrm{T}_{6}$ - Papaya seed extract - 10\% & $75(60.0)$ & 12.9 & 15.2 & 239 & 2102 \\
\hline Mean & 76 & 12.4 & 15.2 & 242 & 18.38 \\
\hline $\mathrm{SEd}$ & 0.89 & 0.23 & 0.25 & 0.004 & 2090 \\
\hline $\mathrm{CD}(\mathrm{P}=0.05)$ & 1.86 & 0.49 & 0.52 & 0.009 & 28.82 & 60.55 \\
\hline
\end{tabular}

Table 4: Effect of seed treatment with pomegranate peel extract on physiological traits in blackgram

\begin{tabular}{lccccc}
\hline Treatment & Germination $\%$ & Shoot length $(\mathrm{cm})$ & Root length $(\mathrm{cm})$ & Dry matter $\left(\mathrm{mg}\right.$ seedlings $\left.{ }^{-10}\right)$ & Vigour index I Vigour index II \\
\hline $\mathrm{T}_{1}$ - Control & $72(58.05)$ & 10.8 & 13.8 & 237 & 1771 \\
\hline $\mathrm{T}_{2}$ - Water soaking & $73(58.70)$ & 11.3 & 14.3 & 236 & 17.06 \\
\hline $\mathrm{T}_{3}$ - Pomegranate peel extract - 2.5\% & $74(59.34)$ & 12.6 & 14.9 & 224 & 1769 \\
\hline $\mathrm{T}_{4}$ - Pomegranate peel extract - 5\% & $77(61.34)$ & 13.3 & 15.6 & 245 & 2031 \\
\hline $\mathrm{T}_{5}$ - Pomegranate peel extract - 7.5\% & $79(62.73)$ & 13.5 & 15.6 & 252 & 16.58 \\
\hline $\mathrm{T}_{6}$ - Pomegranate peel extract - 10\% & $77(61.34)$ & 12.9 & 14.9 & 233 & 2300 \\
\hline Mean & 75 & 12.4 & 14.9 & 238 & 2141 \\
\hline $\mathrm{SEd}$ & 0.99 & 0.07 & 0.20 & 0.003 & 17.91 \\
\hline $\mathrm{CD}(\mathrm{P}=0.05)$ & 2.08 & 0.15 & 0.42 & 0.006 & 17.94 \\
\hline
\end{tabular}

papaya pulp extract $2.5 \%$ all the parameters (Table 2). Papaya pulp is rich source in vitamin $\mathrm{C}$ [22]. So, it might be a reason for increasing the seed germination. The same results were obtained in french bean [23], wheat [24], pea [25] and maize [26].

Results from different concentrations of papaya seed extract showed significant variations in seed germination and seedling growth. Papaya seed extract $2.5 \%$ showed $11.1 \%$ in germination, $21.7 \%$ in root length, $26.5 \%$ in shoot length, $8.4 \%$ in dry matter production, $37.9 \%$ in vigour index I and $20.5 \%$ in vigour index II increased over the control (Table 3 ). Antioxidants protect and prevent oxidative deterioration of lipids [27]. Similarly [28] reported that papaya seeds extracts having strongest DPPH and hydroxyl free radical scavenging activities due to antioxidant properties. So, this may be a reason for the increase in the physiological quality of the blackgram seeds.
Significant differences were noticed in the various concentrations of pomegranate peel extracts on seedling growth. Lower germination $(72 \%)$ was observed in control and it was less than 6.5 per cent then the pomegranate peel extract $7.5 \%(79 \%)$ (Table 4). This might be due to the proanthocyanidins present in pomegranate peel extracts which are having the capacity to enhancing the seed germination. This is in close conformity with the findings of [7] who stated that pomegranate contains some proanthocyanidins in the peel. It had a positive effect on seed germination due to the enhanced antioxidant efficiency by the seed treating in blackgram.

Significant influence was observed in the different concentration of pomegranate seed extract on physiological traits. The germination percentage of seeds soaked with $2.5 \%$ of pomegranate seed extract $(77 \%$ ) with an increase of $6.9 \%$ over untreated seed and $5.5 \%$ over water soaked seed. Similar 
Table 5: Effect of seed treatment with pomegranate seed extract on physiological traits in blackgram

\begin{tabular}{lccccc}
\hline Treatment & Germination \% & Shoot length $(\mathrm{cm})$ & Root length $(\mathrm{cm})$ & Dry matter (mg seedlings $\left.{ }^{-10}\right)$ & Vigour index I Vigour index II \\
\hline $\mathrm{T}_{1}$ - Control & $72(58.05)$ & 10.8 & 13.8 & 237 & 1771 \\
\hline $\mathrm{T}_{2}$ - Water soaking & $73(58.70)$ & 11.3 & 14.3 & 236 & 17.06 \\
\hline $\mathrm{T}_{3}$ - Pomegranate seed extract - 2.5\% & $77(61.34)$ & 11.5 & 15.0 & 252 & 1869 \\
\hline $\mathrm{T}_{4}$ - Pomegranate seed extract - 5\% & $76(60.67)$ & 11.2 & 14.5 & 249 & 17.23 \\
\hline $\mathrm{T}_{5}$ - Pomegranate seed extract - 7.5\% & $74(59.34)$ & 11.4 & 14.3 & 242 & 1953 \\
\hline $\mathrm{T}_{6}$ - Pomegranate seed extract - 10\% & $74(59.34)$ & 10.5 & 14.4 & 231 & 1900 \\
\hline Mean & 74 & 11.1 & 14.4 & 1840 \\
\hline $\mathrm{SEd}$ & 0.62 & 0.20 & 0.19 & 241 & 17.91 \\
\hline $\mathrm{CD}(\mathrm{P}=0.05)$ & 1.30 & 0.43 & 0.40 & 0.004 & 1896 \\
\hline
\end{tabular}

Table 6: Influence of seed treatment with different fruit parts extract on physiological traits in blackgram

\begin{tabular}{|c|c|c|c|c|c|c|}
\hline Treatment & Germination \% & Shoot length $(\mathrm{cm})$ & Root length $(\mathrm{cm})$ & Dry matter ( $m g$ seedlings ${ }^{-10}$ ) & Vigour index I & Vigour index II \\
\hline $\mathrm{T}_{1}$ - Control & $72(58.05)$ & 10.8 & 13.8 & 237 & 1771 & 17.06 \\
\hline $\mathrm{T}_{2}$ - Water soaking & $73(58.70)$ & 11.3 & 14.3 & 236 & 1869 & 17.23 \\
\hline $\mathrm{T}_{3}$ - Papaya peel extract - $5 \%$ & $77(61.34)$ & 12.6 & 15.2 & 258 & 2138 & 19.87 \\
\hline $\mathrm{T}_{4}$ - Papaya pulp extract - $5 \%$ & $75(60.0)$ & 12.6 & 15.7 & 254 & 2126 & 19.05 \\
\hline $\mathrm{T}_{5}$ - Papaya seed extract $-2.5 \%$ & $80(63.44)$ & 13.7 & 16.8 & 257 & 2442 & 20.56 \\
\hline $\mathrm{T}_{6}$ - Pomegranate peel extract $-7.5 \%$ & $79(62.73)$ & 13.5 & 15.6 & 252 & 2300 & 19.91 \\
\hline $\mathrm{T}_{7}$ - Pomegranate seed extract $-2.5 \%$ & $77(61.34)$ & 11.5 & 15.0 & 252 & 2042 & 19.40 \\
\hline Mean & 76 & 12.3 & 15.2 & 249 & 2098 & 19.01 \\
\hline SEd & 0.52 & 0.19 & 0.21 & 0.004 & 35.09 & 0.33 \\
\hline$C D(P=0.05)$ & 1.08 & 0.39 & 0.44 & 0.008 & 72.98 & 0.68 \\
\hline
\end{tabular}

Table 7: Influence of seed treatment on field emergence, protein content and $\alpha$ - amylase activity (mg maltose min-1) of blackgram

\begin{tabular}{|c|c|c|c|}
\hline Treatment & Field emergence \% & Protein content \% & $\alpha$ - amylase activity (mg maltose $\mathrm{min}^{-1}$ ) \\
\hline $\mathrm{T}_{1}$ - Control & $68(55.55)$ & 23.57 & 0.82 \\
\hline $\mathrm{T}_{2}$ - Water soaking & $70(56.79)$ & 23.64 & 0.84 \\
\hline $\mathrm{T}_{3}$ - Papaya peel extract - $5 \%$ & $75(60.0)$ & 23.90 & 0.97 \\
\hline $\mathrm{T}_{4}$ - Papaya pulp extract - $5 \%$ & $72(58.05)$ & 23.72 & 0.87 \\
\hline $\mathrm{T}_{5}$ - Papaya seed extract $-2.5 \%$ & $77(61.34)$ & 24.09 & 1.13 \\
\hline $\mathrm{T}_{6}$ - Pomegranate peel extract $-7.5 \%$ & $75(60.0)$ & 23.91 & 1.08 \\
\hline $\mathrm{T}_{7}$ - Pomegranate seed extract $-2.5 \%$ & $74(59.34)$ & 23.87 & 0.91 \\
\hline Mean & 73 & 23.81 & 0.95 \\
\hline SEd & 0.63 & 0.42 & 0.01 \\
\hline$C D(P=0.05)$ & 1.30 & NS & 0.03 \\
\hline
\end{tabular}

response was observed in all other parameters, followed by pomegranate seed extracts $5 \%$ (Table 5). Increase in quality of blackgram seeds due to treated with pomegranate seed extracts might be attributed to the presence of vitamin tocopherol and antioxidant $[29,30]$.

The seed soaking with different fruit parts extract had a significant effect on the seed germination, seedling length, dry matter production, vigour index in blackgram. The papaya seed extract $2.5 \%$ highest seed germination and all other parameters. Followed by the pomegranate peel extract $7.5 \%$ and papaya peel extract $5 \%$ (Table 6). Both the fruit parts extract of have higher antioxidant activity and contains the several minerals described by many researchers $[4,29,31,32,33,34]$.
Significant differences were noticed in field emergence and $\alpha$ - amylase activity in different fruit extracts. Highest value was observed in papaya seed $2.5 \%$ extract for field emergence $(77 \%)$ and $\alpha$ - amylase activity $\left(1.13 \mathrm{mg}\right.$ maltose $\left.\mathrm{min}^{-1}\right)$, followed by pomegranate peel extract $7.5 \%$, papaya peel extract $5 \%$, lowest value was observed in control for field emergence $(68 \%)$ and $\alpha$ - amylase activity $\left(0.82 \mathrm{mg}\right.$ maltose $\left.\mathrm{min}^{-1}\right)$. There was a nonsignificant difference in protein content on among the fruit part extracts (Table 7 ). The enhanced $\alpha$-amylase enzyme activity in treated seeds may be due to imbibition of seed which increase lead to hydrolysis. The produce $\alpha$ - amylase enzyme was retained even after redrying back to initial moisture content [35]. Similar result was obtained in rice [36]. 


\section{CONCLUSION}

The present study shown that papaya seed extract $2.5 \%$ recorded maximum germination per cent, seedling length, dry matter production and vigour index, followed by pomegranate peel extract $7.5 \%$, papaya peel extract $5 \%$. So, we can conclude that the $2.5 \%$ of papaya seed extract can be effectively used for seed treatment in blackgram seed quality improvement.

\section{AUTHOR'S CONTRIBUTIONS}

Poovarasan. T designed experiment, interpreted data and writing an original draft. Lakshmi. S participated in the review and editing. Renugadevi. J and Senthil. A for conceptualization, validation of the manuscript.

\section{REFERENCES}

1. McDonald MB. Seed priming. Seed technology and its biological basis. 2000:287-325.

2. John JA, Shahidi F. Phenolic compounds and antioxidant activity of Brazil nut (Bertholletia excelsa). Journal of Functional Foods. 2010;2:196-209.

3. Okonogi S, Duangrat C, Anuchpreeda S, Tachakittirungrod S, Chowwanapoonpohn S. Comparison of antioxidant capacities and cytotoxicities of certain fruit peels. Food Chemistry. 2007; 103:839-846.

4. Martial-Didier AK, Hubert KK, Parfait KE, Kablan T. Phytochemical Properties and Proximate Composition of Papaya (Carica papaya L. var solo 8) Peels. Turkish Journal of Agriculture-Food Science and Technology. 2017;5:676-680.

5. OECD. Consensus document on compositional consideration for new varieties of papaya (Carica papaya): key food and feed nutrients, anti-nutrients, toxicants and allergens www.eocd.org/biotrack. 2010.

6. Ang YK, Sia WC, Khoo HE, Yim HS. Antioxidant potential of Carica papaya peel and seed. Focusing on Modern Food Industry. 2012;1:11-16.

7. Mirdehghan SH, Rahemi M. Seasonal changes of mineral nutrients and phenolics in pomegranate (Punica granatum L.) fruit. Scientia Horticulturae. 2007;111:120-127.

8. Jaiswal V, DerMarderosian A, Porter JR. Anthocyanins and polyphenol oxidase from dried arils of pomegranate (Punica granatum $\mathrm{L}$.). Food Chemistry. 2010;118:11-16.

9. El-Nemr SE, Ismail IA, Ragab M. Chemical composition of juice and seeds of pomegranate fruit. Food/Nahrung. 1990:34:601-606.

10. Singh RP, Gupta AK, Bhatia AK. Utilization of Wild Pomegranate in Northwest Himalayas-Status and Problems. Proc Nat Semi Production and Marketing of Indigenius Fruits. 1990:100-107.

11. Singh $D$, Sethi V. Screening of pomegranate genotypes for the preparation of quality grade anardana. Journal of food science and technology. 2003;40:236-238.

12. Syed DN, Afaq F, Mukhtar H. Pomegranate derived products for cancer chemoprevention. InSeminars in cancer biology. 2007;17:377-385.

13. Govindaraj M, Masilamani P, Albert VA, Bhaskaran M. Role of antioxidant in seed quality-A review. Agricultural Reviews. 2017:38:180-190

14. ISTA. International rules for seed testing. International Seed Testing Association, Bassersdorf, Switzerland; 2012.

15. Abdul-Baki AA, Anderson JD. Vigor determination in soybean seed by multiple criteria 1. Crop science. 1973;13:630-633.

16. Reddy YT, Khan MM. Effect of osmopriming on germination, seedling growth and vigour of khirni (Mimusops hexandra) seeds. Seed
Research-New Delhi. 2001:29:24-27.

17. Ali-Khan ST, Youngs CG. Variation in protein content of field peas. Canadian Journal of Plant Science. 1973:53:37-41.

18. Paul AK, Mukherji S, Sircar SM. Metabolic changes in rice seeds during storage. Indian Journal of Agricultural Science. 1970;40:1031-1036.

19. Panse VG, Sukhatme PV. In: Statistical methods for agricultural workers. 1985:97-164

20. Santos CM, Abreu CM, Freire JM, Queiroz ED, Mendonça MM. Chemical characterization of the flour of peel and seed from two papaya cultivars. Food Science and Technology. 2014;34:353-357.

21. Woodstock LW, Maxon S, Faul K, Bass L. Use of freeze-drying and acetone impregnation with natural and synthetic anti-oxidants to improve storability of onion, pepper, and parsley seeds [Allium cepa, Capsicum annuum, Petroselinum crispum]. Journal American Society for Horticultural Science. 1983;108:692-696.

22. Spínola V, Pinto J, Castilho PC. Identification and quantification of phenolic compounds of selected fruits from Madeira Island by HPLC-DAD-ESI-MSn and screening for their antioxidant activity. Food chemistry. 2015:173:14-30.

23. Innocenti AM, Mazzuca S, Bitonti MB, De Gara L, Liso R, Arrigoni O. Endogenous rhythm of ascorbic acid in seedling roots of broad bean. Plant Physiology and Biochemistry (France). 1994;32:521-525.

24. De Gara LD, De Pinto MC, Arrigoni O. Ascorbate synthesis and ascorbate peroxidase activity during the early stage of wheat germination. Physiologia Plantarum. 1997;100:894-900

25. Pallanca JE, Smirnoff N. Ascorbic Acid Metabolism in Pea Seedlings. A Comparison of d-Glucosone, I-Sorbosone, andl-Galactono-1, 4-Lactone as Ascorbate Precursors. Plant Physiology. 1999;120:453-462.

26. De Gara L, Paciolla C, De Tullio MC, Motto M, Arrigoni O. Ascorbatedependent hydrogen peroxide detoxification and ascorbate regeneration during germination of a highly productive maize hybrid: Evidence of an improved detoxification mechanism against reactive oxygen species. Physiologia Plantarum. 2000;109:7-13.

27. Mathur, P. Natural antioxidants our diet. Nutrition. 1997;31:10-17

28. Zhou K, Wang H, Mei W, Li X, Luo Y, Dai H. Antioxidant activity of papaya seed extracts. Molecules. 2011;16:6179-6192.

29. Prakash CV, Prakash I. Bioactive chemical constituents from pomegranate (Punica granatum) juice, seed and peel-a review. International Journal of Research in Chemistry and Environment. 2011:1:1-18.

30. Singh RP, Chidambara Murthy KN, Jayaprakasha GK. Studies on the antioxidant activity of pomegranate (Punica granatum) peel and seed extracts using in vitro models. Journal of agricultural and food chemistry. 2002; 50:81-86

31. Bari L, Hassan P, Absar N, Haque ME, Khuda MI, Pervin MM, Khatun S, Hossain MI. Nutritional analysis of two local varieties of papaya (Carica papaya L.) at different maturation stages. Pakistan Journal of Biological Sciences. 2006;9:137-140.

32. Adetuyi FO, Akinadewo LT, Omosuli SV, Ajala L. Antinutrient and antioxidant quality of waxed and unwaxed pawpaw Carica papaya fruit stored at different temperatures. African Journal of Biotechnology. 2008;7:2920-2924.

33. Negi PS, Jayaprakasha GK, Jena BS. Antioxidant and antimutagenic activities of pomegranate peel extracts. Food chemistry. 2003:80:393-397.

34. USDA (United States Department of Agriculture), Agricultural Research service. National Nutrient Database for standard reference, release 22, Nutrient data laboratory home page, http://www.ars.usda. gov./ba/bhnrc/nol. 2009

35. Afzal I, Basra SM, Shahid M, Farooq M, Saleem M. Priming enhances germination of spring maize (Zea mays L.) under cool conditions. Seed Science and Technology. 2008;36:497-503.

36. Lee SS, Kim JH. Total sugars, $\alpha$-amylase activity, and germination after priming of normal and aged rice seeds. Korean Journal of Crop Science. 2000;45:108-111. 